\title{
The role of organic solutes in the osmotic adjustment of chilling-stressed plants (vegetable, ornamental and crop plants)
}

\author{
Seyedeh Somayyeh Shafiei Masouleh ${ }^{1^{*}}$, Narjes Jamal Aldine ${ }^{2,3}$, Youssef Najib Sassine
}

\begin{abstract}
Various abiotic stresses affect growth and development of plants and two important cues that cause to sever decrease the horticultural and crops yield are the heat and chilling stresses worldwide. Plants have various mechanisms to tolerate or avoid the stresses; one of these mechanisms is the biosynthesis of organic solutes. In this paper, effects of chilling $\left(0-15^{\circ} \mathrm{C}\right)$ stress on the horticultural (ornamental and vegetable) plants and crops are discussed. You will see that plants how to tolerate the stress by organic solutes. The most important organic molecules to regulate water relations in plants are introduced. The organic solutes that also are called osmo-protectants include soluble carbohydrates, amino acids and nitrogen compounds.
\end{abstract}

Keywords: Abiotic stresses, cold stress, flowers, osmo-protectants.

\section{Introduction}

During optimum processes of growth and development, various kinds of stresses, including drought, heat, UV light, air pollution, and pathogen factors have an influence on plants (Rivero et al., 2001). These environmental agents unfavorably affect growth, development, and final performance of plant. According to the statistics, maybe only $\leq 10 \%$ of farms in the world is without major environmental stresses (Ashraf et al., 2007). In stress conditions, plants have two types of adaptive behavior: tolerance or avoidance. Plants with tolerance mechanisms have high metabolic activity under mild stress, and severe stress reduces their activities. Plants with avoidance mechanisms have the reduced autotrophic activity and in the face of extreme stress are in dormancy. In agricultural plant breeding are looking for the plants that reduce stress effects with avoidance mechanisms, for instance by suitable seasonal phenology. This strategy may already give large effects, but further selection in this direction may make a limited or perhaps negative impact on productivity in stress conditions (Osmond et al., 1987). It is necessary to promote plant tolerance to abiotic stress in order to enhance productivity under water deficit conditions, salinity, and cold stress (Latef and Chaoxing, 2011). Tolerance mechanisms to environmental stresses are very complicated at entire plant and cell levels (Figure 1). The reason of this is the complexities of the stress agents and different phenomena (including molecule, biochemistry and physiology) interactions that affect growth and development of plants. Nowadays, there are no economic and suitable technologies to simplify plant production under stress statuses.

Plants mostly experience the damages physiologically and biochemically when temperature is higher or lower than optimum. These injuries affect the majority of metabolic processes, and reduce growth rates of plants and finally cause lower economic performance. It can be said that heat stress causes plants to produce phenolic compounds including flavonoids and phenylpropanoids that lead to damages (Rivero et al., 2001). Ambient temperatures change more rapid toward other stress agents, including drought, salinity and nutrient imbalances. Cold stress, although seasonal, is a little similar to water deficit stress, because, during freezing water it causes the concentrated solutes, then plants experience deficit liquid water (Ashraf et al., 2007). The cold and heat stresses are very crucial for performance of agricultural products among abiotic stresses. When environment is at optimum temperature, plants are with a most growth and development. However, physiology, biochemistry, metabolic and molecular statuses of plants will be changed when ambient temperature changes from optimum. Actually, this is a plant effort to increase growth and developmental activities and

\footnotetext{
${ }^{1}$ Department of Genetics and Breeding, Ornamental Plants Research Center (OPRC), Horticultural Sciences Research Institute (HSRI), Agricultural Research, Education and Extension Organization (AREEO), Mahallat, Iran. *Corresponding author: shafiee.masouleh@areeo.ac.ir ${ }^{2}$ Lebanese University, Faculty of Agricultural Engineering and Veterinary Sciences, Department of Plant Production, Beirut, Lebanon ${ }^{3}$ University of Forestry, Sofia, Bulgaria
} 
leads plants to keep cell homeostasis when statuses are unfavorable. Plants experience gradually more unusual, damaged or bad function of cellular processes in entire plant under increasingly stress conditions until reaching the cardinal temperatures for survival. When an extreme natural temperature affects plants, the intensity of plant activities will be increased at the levels of cells and molecules, and these causes the plant death (Yadav, 2010).

Plant cells similar to the other organisms understand and process signals by different receptors on the cell surface, which are exposed to (Upadhyaya et al., 2013).

This may cause the cellular adaptive reactions alike, including production of compatible osmolytes, expression of stress proteins, and activation of scavenging systems of ROS. Generally, plants are saved from damage throughout different techniques, which includes role in osmotic adjustment of cells, detoxification of ROS, integrity of membrane, preservation of enzymes steady. In addition, these osmolytes are known as osmoprotectants because they preserve cellular constituents against dehydration. Osmolytes comprise sucrose, trehalose, alanine betaine, glycine betaine, proline betaine, polyols, choline $O$-sulfate, proline, pipecolate betaine and hydroxyproline betaine (Ashraf et al., 2007). Two ways of metabolism modification occur in plants when are under temperature alterations. First, plants make an effort to adapt their cellular metabolism to heat and cold stress. These stresses alter structurally, catalytically and functionally enzymes and metabolite transporters in the membrane. Remarkably, with acting regulatory mechanisms in plants, it functions to restore optimum metabolite levels, especially metabolic fluxes. Second, the alterations of metabolism during temperature stress cause the promoted mechanisms for tolerance. It can be said that there are many metabolites to induce stress responses (Yadav, 2010).

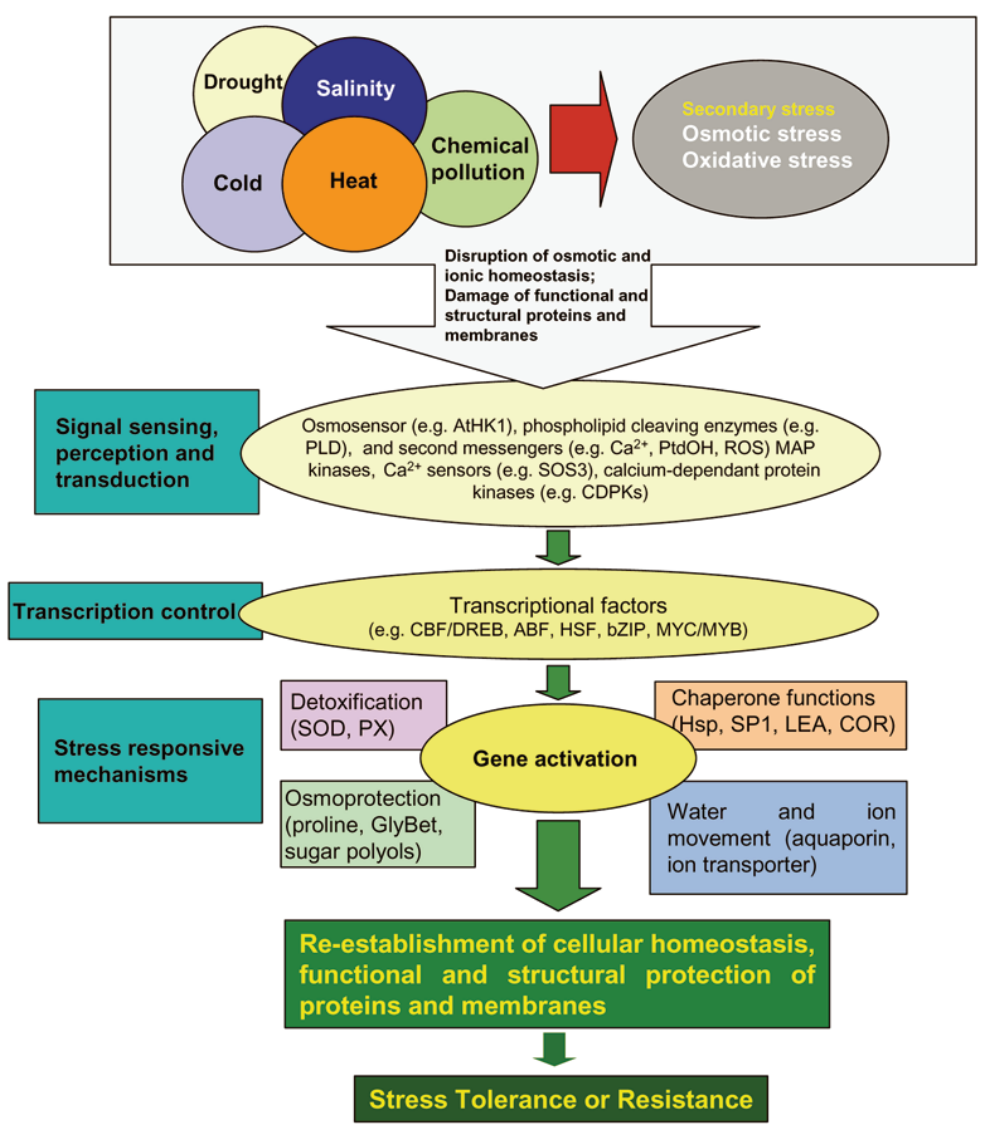

Figure 1. Complexity of plant responses to primary abiotic stresses and triggering secondary stresses (osmotic and oxidative stresses) (Wang et al., 2003)

In this paper, chilling stress and its effects on the various species of plants (including examples of vegetative and ornamental plants and crops) are discussed and plant mechanisms for tolerance through organic solutes are interpreted. In Table 1, specifically is it possible to find different responses of ornamental plants to the chilling stress. About these reactions will be discussed at other following sections. 
Table 1. Different responses of ornamental plants to chilling stress as tolerance mechanisms

\begin{tabular}{|c|c|c|c|c|}
\hline No. & Plants & $\begin{array}{l}\text { Stress } \\
\text { conditions }\end{array}$ & Plant response & Reference \\
\hline 1 & $\begin{array}{l}\text { Lolium perenne } \\
\text { and Festuca } \\
\text { arundinacea }\end{array}$ & $\begin{array}{l}\text { Heat or cold } \\
\text { stress }\end{array}$ & $\begin{array}{l}\text { Severe response of } H s f s \text { to high and low temperature in three } \\
\text { class, including } H s f A \text { s under high temperature stress, particularly } \\
\text { in } H_{s f A 2} \text {, the most } H s f B s \text { by the both temperature conditions, } \\
\text { and } H s f C s \text { under low temperature stress. The target genes of } H s f s \\
\text { were inositol-3-phosphate synthase (IPS), heat shock protein } \\
(H S P) \text {, ascorbate peroxidase }(A P X) \text { and galactinol synthase } \\
\qquad(G O L S 1) \text {. }\end{array}$ & $\begin{array}{l}\text { Wang et } \\
\text { al. (2016) }\end{array}$ \\
\hline 2 & $\begin{array}{l}\text { Bermudagrass } \\
\text { (Cynodon dactylon } \\
\text { L. Pers.) }\end{array}$ & Cold stress & $\begin{array}{l}\text { Exogenous ABA changed the expression of ABA- or cold related } \\
\text { genes, }(L E A, A B F 1 \text {, and } C B F 1) \text { in both resistance and sensitive } \\
\text { plants. }\end{array}$ & $\begin{array}{l}\text { Huang et } \\
\text { al. (2017) }\end{array}$ \\
\hline 3 & $\begin{array}{l}\text { Galanthus nivalis } \\
\text { L. }\end{array}$ & Chilling stress & $\begin{array}{l}\text { The application of sucrose on leaves of } G \text {. nivalis affected } \\
\text { ultrastructure of photosynthetic apparatus and function, that } \\
\text { means, the capability of chloroplasts are capable for osmotic } \\
\text { adjustment under cold stress. }\end{array}$ & $\begin{array}{l}\text { Fediuk et } \\
\text { al. (2017) }\end{array}$ \\
\hline 4 & $\begin{array}{l}\text { Dendranthema } \\
\text { grandiflorum }\end{array}$ & Low temperature & $\begin{array}{c}\text { Accumulating soluble sugar and then osmotic adjustment, } \\
\text { decreasing cell water potential and promoting water holding } \\
\text { capacity. } \\
\text { Being sugar as carbon source for cold resistance and } \\
\text { physiological and biochemical process, with enhancement of } \\
\text { cold resistance. }\end{array}$ & $\begin{array}{l}\text { Wang et } \\
\text { al. (2018) }\end{array}$ \\
\hline 5 & Lilium lancifolium & Cold stress & $\begin{array}{c}\text { Expression of key genes of polyamines and anthocyanin } \\
\text { biosynthesis as COR genes (cold-regulated genes) (FLS, CHS, } \\
\text { C4H, ADC and 4CL2). }\end{array}$ & $\begin{array}{l}\text { Yong et al. } \\
\text { (2018) }\end{array}$ \\
\hline 6 & $\begin{array}{l}\text { Lilium lancifolium } \\
\text { Thunb. }\end{array}$ & $\begin{array}{l}\text { Cold storage- } \\
\text { browning of } \\
\text { bulbs }\end{array}$ & $\begin{array}{l}\text { For inhibition of bulb browning, heat treatment is effective, } \\
\text { because of stimulating the activities of superoxide dismutase and } \\
\text { catalase, inhibiting lipoxygenase activity and malondialdehyde } \\
\text { accumulation, total phenol content and the activities of } \\
\text { polyphenol oxidase, phenylalanine ammonialyase and } \\
\text { peroxidase. }\end{array}$ & $\begin{array}{l}\text { Kan et al. } \\
\text { (2019) }\end{array}$ \\
\hline 7 & $\begin{array}{l}\text { Artemisia judaica } \\
\text { L. }\end{array}$ & $\begin{array}{c}\text { Extreme } \\
\text { temperatures }\end{array}$ & $\begin{array}{l}\text { Suppressing plant growth, activation of catalase, carbonic } \\
\text { anhydrase, superoxide dismutase and peroxidase for coping with } \\
\text { the very cold temperature and very heat condition. }\end{array}$ & $\begin{array}{l}\text { Abbas et } \\
\text { al. (2017) }\end{array}$ \\
\hline 8 & $\begin{array}{l}\text { Hevea brasiliensis } \\
\text { Muell. Arg. }\end{array}$ & Cold stress & $\begin{array}{l}\text { Down-regulation of ethylene and auxin signaling and activation } \\
\text { of ROS scavengers and heat shock module as a primary way for } \\
\text { coping with low temperature stress }\end{array}$ & $\begin{array}{l}\text { Deng et al. } \\
\quad(2018)\end{array}$ \\
\hline 9 & Kandelia obovata & Cold stress & $\begin{array}{l}\text { The KoHsp70 (primary member of HSPs) was a stress-inducible } \\
\text { gene in cold stress to cope with stresses. }\end{array}$ & $\begin{array}{l}\text { Fei et al. } \\
(2015)\end{array}$ \\
\hline 10 & $\begin{array}{l}\text { Dianthus } \\
\text { spiculifolius }\end{array}$ & $\begin{array}{l}\text { Cold and drought } \\
\text { stress }\end{array}$ & $\begin{array}{l}\text { Observation of expression of overlapped and cross-talk genes } \\
\text { between cold and drought stress response pathways. }\end{array}$ & $\begin{array}{l}\text { Zhou et al. } \\
\text { (2017) }\end{array}$ \\
\hline
\end{tabular}




\section{Chilling stress}

Low temperature is a main environmental stress that influences plant's growth and its natural distribution. Under cold stress, the physiological processes such as water status and photosynthesis will undergo different modifications in most crops. In addition, low temperature alters the water uptake and absorption by plant through decreasing the hydraulic conductance and losing the stomata control. Furthermore, cold stress minimizes the photosynthesis capacities and efficiencies by changing the pigment ratios, decreasing the chlorophyll fluorescence and reducing chloroplast development (Latef and Chaoxing, 2011). Chilling stress is one of the important environmental stresses that restrict the performance of plant by having influence on its postharvest life (Yadav, 2010). Chilling has various influences on ROS, enzyme activities, and photosystem function. It also leads to leaves damage, male sterility and loss in plant production. This effect can be explained due to ATP synthesis reduction and contents of phosphatidylglycerol in thylakoid membrane lipids. Furthermore, cold stress causes changes in chloroplast structure of the leaves due to swelling or disintegration of thylakoid membranes without remarkable leaf color change (Wang et al., 2016).

Cold stress firstly alters the cell membrane in the plant through increasing its permeability. At the same time, various ROS, including hydroxyl radicals $\left({ }^{\circ} \mathrm{OH}\right)$, superoxide anion radical $\left(\mathrm{O}_{2}^{\bullet-}\right)$ and hydrogen peroxide $\left(\mathrm{H}_{2} \mathrm{O}_{2}\right)$, are constructed due to a loss imbalance between production and scavenging in the cell which leads to peroxidation of the lipid membrane. Therefore, plants must preserve themselves from oxidative damage; they induce osmotic adjustment and antioxidant enzyme activities, including catalase, superoxide dismutase peroxidase, and glutathione reductase, ascorbate peroxidase and a number of non-enzymatic antioxidants including ascorbic acid, phenolic substances, $\alpha$-tocopherols and decreased glutathione (Latef and Chaoxing, 2011).

Plants in reaction to low temperature change their photosynthetic and non-photosynthetic pigments. The chilling stress affects the contents of $C h l$ as well as the absorption efficiency of $\mathrm{Chl}$ is reduced and the contents of carotenoids. Besides, a noticeable decline of photosystem II maximum efficiency $(\mathrm{Fv} / \mathrm{Fm})$, electron transport rates (ETR) and phtochemical quenching $(\mathrm{qP})$ in the chilling-stress leaves can be determined a potential damaging effect of light on photosystem II as well as changes of chloroplast structure (Wang et al., 2016). To decrease chlorophyll content and giving rise to more content of carotenoids in the plant must be considered as one of the most significant changes resulting from cold stress (Latef and Chaoxing, 2011).

Anthocyanins pigments are among the most important pigments responsible for giving the flowers red, purple and blue colors. Anthocyanin accumulation in plant tissues is affected by temperature as a main external cue: anthocyanin content increases when plants are affected by cold stress while it decreases upon exposure to high temperature. High temperature stress causes the synthesis of low content of anthocyanin by plants. Anthocyanin genes are greatly revealed by temperature; in which cold stress greatly elevates the transcript levels of genes. The products of these genes are important to synthesize pigments.

Key enzymes in the general phenylpropanoid pathway, including phenylalanine ammonia lyase and enzymes that catalyze reactions related to flavonoid and anthocyanin biosynthesis, including chalcone isomerase, chalcone synthase and dihydroflavonol reductase are among of these products. Moreover, temperature influences pigment stability in which high temperature causes increase in pigment degradation. Anthocyanin synthesis is a fundamental process for development of flower. When flavonoids are synthesized in the flower petals, this leads to growth of tissue and is under developmental power. Different genes in the biosynthetic pathway, including chs, $d f r, p a l$ and $c h i$ will be expressed in the early phases of flower development. However, their expression will be reduced at later phases (flowering), in apple, Petunia, rose and Antirrhinum flowers. Roses, which are globally considered as most important ornamental plants are affected by temperature. It affects its color, which is economically an important trait. In addition, at low temperature levels, anthocyanin contents increase, while it decreases when the growth temperature has been held high. In addition, unique vulnerability of buds to cold stress levels is enough to raise anthocyanin biosynthesis. The levels of enzymes chalcone synthase and dihydroflavonol 4-reductase may be altered due to either low transcription rate of these genes or low stability of mRNA. The continued prevention of anthocyanin buildup even by stopping heat stress is due to high temperature effects on the levels of transcripts. Additional transcripts or enzymes could be synthesized under variation of temperature and anthocyanin levels (Dela et al., 2003).

Chilling stress is a main feature that limits growth cycle of rice, because it is considered as a tropical plant. Rice germination, seedlings development, heading and seed formation are all affected by chilling stress. Besides, the rice yield chilling-tolerant mechanism is tightly linked to the photosynthetic rate, ROS metabolism, and ROS scavenging system (Wang et al., 2016). Plants can withstand chilling temperatures from zero to $15{ }^{\circ} \mathrm{C}$ in order to maintain homeostasis for acquiring freezing tolerance, in which this occurs with extensive resetting of gene expression and metabolism. Lately, the majority of analyses have focused on explanation of the complex pathways of signal transduction that are responsible for low temperature reactions (Yadav, 2010). All cellular function in plant can be affected by cold stress. Disintegration of membrane is considered one of the most causes of low temperature stress-induced dehydration. These cold stress-caused variations unfavorably affect the growth and development of plants (Yadav, 2010). Sensitive plants to chilling stress are not affected by cold stress in without of low light environments. Nevertheless, they are affected by low temperature as reducing photosynthetic activity and this show a relationship between the effects of low temperature and light (Hare and Cress, 1997). 
The synthesis of phenylpropanoids will be increased by stimulation of different abiotic and biotic stresses such as UV light, high intensity of light, pathogen attack, drought, cold stress and nutrient deficiencies increase. For example, proline biosynthesis, cold and pathogen-induced biosynthesis of chalcone synthase and phenylalanine ammonialyase transcripts in Arabidopsis is dependent to the light (Hare and Cress, 1997). Chilling stress leads to reduce the membrane proteins in Clerodendrum plants resulting from either decreased synthesis or increased degradation. Recently, all evidences showed that ubiquitin is a key protein to control the metabolism of cellular protein. Ubiquitin is known as greatly preserved 76-amino acid polypeptide, which is concerned in the degradation of ATP-dependent protein in eukaryotic cells. In addition, ubiquitination plays a role in responding to different abiotic stresses in eukaryotic cells including those related to high temperatures. Heat stress leads to the increase in ubiquitin conjugation to root proteins of wheat; also, chilling stress promotes ubiquitin conjugation to proteins of Clerodendrum leaf, primarily to the membrane proteins in plants. It seems that this is because of converting of free ubiquitin to the conjugated form. Consequently, soluble and membrane proteins will be more lost after chilling. It is possible that chilling stress modify leaf proteins directly or indirectly, and here ubiquitination stands as a way for the tissue to destroy these proteins by promoting of specific proteolysis (Gindin and Borochov, 1992).

Acclimation to cold is a process in which plants in mild areas perceive chilling and low temperature conditions before being exposed to severe low cold stress. However, various plants cannot have cold acclimation yet. Chillingtolerant plant is able to grow during exposure to low or nonfreezing temperatures $\left(0-15{ }^{\circ} \mathrm{C}\right)$ without being damaged (Yadav, 2010). Chilling-tolerant mechanism is known to be tightly linked to the photosynthetic rate, ROS metabolism and scavenging system of them (Wang et al., 2016).

Low temperature conditions change approximately all biological actions in plants. These cold stress-induced changes unfavorably affect the agricultural performance. The receptors that receive low temperature stress in plants are still unknown. The signal of cold stress is transduced by a variety of pathways. The most important constituents are protein phosphatase, calcium, protein kinase, ROS, and lipid signaling cascades. In addition, abscisic acid (ABA) has a main role that responds to cold stress. The signal of low temperature stress causes plants to control transcription factors and effector genes, which are known as regulating. Proteins, including late embryogenesis abundant proteins, chaperones, osmotin, mRNA-binding proteins, antifreeze proteins, key enzymes for osmolyte biosynthesis, including proline, sugar water channel proteins and proline transporters, enzymes for fatty acid metabolism, detoxification enzymes, proteinase inhibitors, lipid-transfer proteins and ferritin are coded by effector genes.

The factors of transcription that respond to low temperature conditions induce the $\mathrm{C}$-repeat binding factors, C-repeat binding factor expression-1, mitogen-activated protein kinase and myeloblasts. It is obvious that there are the pathways of multiple signal transductions between the initial stress signals and gene expression. Therefore, the transcription factors and effector genes could be used in genetic modification of plants to produce cold-tolerant crops with improved productivity (Yadav, 2010).

\section{Organic solutes}

Osmolytes have a role to regulate relations of cellular water and reduce dehydration of cells. The characteristics of these compounds permit them to work as stabilizing enzymes, membranes and other cellular constituents. In addition, Osmolytes reconstruct membrane lipid composition for improvement of liquid or crystalline structure needed for suitable function of membrane and sources of energy. These metabolites comprise organic acids, amino acids, soluble sugars, polyamines and lipids (Yadav, 2010).

The increased accumulation of various compatible organic osmolytes can be as one of the main responses of plants against stress. Compatible osmolytes are the compounds with low molecular weight and highly soluble. These compounds are typically nontoxic at high concentrations in cells (Ashraf et al., 2007). Osmoprotectant solutes including hydroxycetoine, ectoine, sucrose, betaine, maltose and trehalose have the ability to preserve lactic dehydrogenase and phosphofructokinase against abiotic stresses. These two enzymes have their high sensitivity towards stress factors (Lippert and Galinski, 1992).

The biosynthesis of organic osmolytes (such as polyols, betaines and other dipolar quaternary ammonium compounds) is considered as a well-characterized biochemical reaction of cells to drought stress in plants. It seems that the accumulation of cytoplasmic osmolytes will reduce water potential of cells toward environment water potential and avoid harmful ionic power. This causes the water to flow into the cell and keep it there and the turgor pressure is maintained for continued growth. Many amino acids that accumulate in response to osmotic stress are introduced, but it seems that proline has a specific protective role to adapt plant cells to lack of water and is likely the preferred organic osmoticum in many plants (Hare and Cress, 1997).

Proline and glycine betaine as main organic compounds are biosynthesized in crops under environmental stresses, including UV radiation, water deficit, severe changes of temperatures, salinity and heavy metals. However, these true osmo-tolerance functions of plants have been remained questionable and it seems that both compounds have positive impact on integrity of enzyme and membrane; also they are mediators for osmotic adaptations in plants that are exposure to stress (Ashraf et al., 2007).

Compatible solutes may have a specific manner on different enzymes. Ectoines and trehalose are cryoprotectants with specific manner, whereas betaine and maltose vary significantly depending on the stress and enzyme. For instance, to preserve the plants against water deficit stress needs to a particular solute to acquire stabilization. During water deficit stress, the interaction of the solute (possibly via -OH groups) and the protein is occurred very direct and specific. For example, the 
protecting potential of compatible solutes without -OH groups (ectoine and betaine) are not usually high. Because, pairing ectoine or hydroxyectoine are occurred through only one -OH group. Hydroxyectoine is considered as a special protecting solute even more than all other solutes and leads even to remove the trehalose effects as a protection against freeze-drying conditions. Ectoine is among of nitrogencontaining solutes (Lippert and Galinski, 1992).

Upon exposure to salty soils, accumulation of organic osmolytes such as valine, proline, isoleucine, aspartic acid, ectoine, betaine, fructose, glucose, sucrose, mannitol, fructans, pinitol and myo-inositol (inositol) is occurred in the cytoplasm of plant cells. Generally, accumulating organic osmolytes in plants is based on raising the rate of their synthesizing, but only a few cases of them involve in osmoregulatory mechanisms. For instance, mannitol synthesis is done by the activation of mannose-6-phosphate reductase in celery plants.

A modification in Arabidopsis, which produces the nonmannitol compounds, with this gene causes to increase salt tolerance. In addition, we have an example about tomato plants that can improve sucrose content and sucrosephosphate synthase activity in salinity. Furthermore, plants similar to bacteria can synthesize glycine betaine by two-phase oxidation of choline through betaine aldehyde as intermediate molecule. The stressed plants can partly increase its accumulation in their leaves through alterations in the genes expression of enzymes that biosynthesize it. However, the signals that affect gene expression are still unknown (Burg and Ferraris, 2008).

\section{Proline}

Many species of plants accumulate proline under unfavorable statuses and this is association with to stress tolerance, in which proline concentration in stress tolerant plants is higher than that in stress-sensitive plants. Proline is a type of amino acids that is widely found in plants and usually biosynthesized in great content in response to abiotic and biotic stresses. Praline's role is not only restricted in contribution as an osmolyte, but also it stabilizes various compartments of cells (e.g. proteins and membranes), scavenges free radicals and buffers redox potential of cells against stressful statuses (Ashraf et al., 2007). Also, proline can be act as primer for the citric acid cycle (TCA cycle) activity, which recovers from osmotic stress. Proline is the primary mitochondrial energy source that can contribute to heat generation in the voodoo lily (Hare and Cress, 1997). Yuan et al. (2011) pretreated the seedlings of Freesia in $38^{\circ} \mathrm{C}$ for $6 \mathrm{~h}$ and then recovered them in $22^{\circ} \mathrm{C}$ for $72 \mathrm{~h}$, then grow plants in heat stress condition $\left(30{ }^{\circ} \mathrm{C}\right)$. They reported that pretreated seedlings showed thermotolerance with higher levels of soluble sugars and proline.

Plants can accumulate free proline against various biotic and abiotic unfavorable statuses. It is believed that this changes in nitrogen metabolism can be benefit for plants when are exposure to abiotic stresses. It is often said that this phenomenon is due to the ability of proline to assist osmotic adjustment, stabilization of different compartments of cells and scavenging free radicals.
However, even after the exposure to stress, the pool size of free proline in cytoplasm is not sufficient for biophysical effects. However, many stresses that induce proline buildup in crops (such as: heavy metal toxicity, nutrient deficiencies, atmospheric pollution and photo-oxidative stress) do not have large osmotic part. After cold-hardening for both chilling and freezing, proline levels increase, while the availability of water is reduced for both stresses. This indicates that proline accumulation by high temperature stress is independently initiated toward water balance of tissue other reasons that show functional significance of the phenomenon (Hare and Cress, 1997). For accumulation of proline in high temperature light is needed. This could be found in roots which are the first tissues to recognize salt stress but free proline levels are lower in osmotic stressed roots than in shoot (Hare and Cress, 1997).

Proline contents may decrease stress-caused acidification of the cells or most important oxidative respiration to supply the recovery energy. Plants may keep NAD $(\mathrm{P})^{+} / \mathrm{NAD}(\mathrm{P}) \mathrm{H}$ ratios at high levels in stress conditions compared to normal ones. And proline biosynthesis might help the increased $\mathrm{NADP}^{+} / \mathrm{NADPH}$ ratio and improve the activity of oxidative pentose phosphate pathway. Therefore, precursors will be produced to increase secondary metabolic output during unfavorable conditions in addition to nucleotide synthesis along with the high rate of cell division. It can be said that proline oxidation may produce a main energy source for ADP phosphorylation.

Metabolic processes for synthesis and degradation of proline are sensitive and may be beneficial to regulate metabolic processes unfavorably affected by environment. This hypothesis is supported on the basis that other physiological phenomena are not directly related to stress responses, so that metabolism of proline may play a regulatory role (Hare and Cress, 1997).

Accumulated proline appears to be protecting enzymes, membranes and polyribosomes during abiotic stresses. Proline is synthesized from glutamate in the cytosol and partly in the chloroplast. During the synthesis of proline, NADPH is used to reduce glutamate, which increases the availability of $\mathrm{NADP}^{+}$, which is required to reduce excessive PSI during adverse statuses in addition to promoting the ratio of $\mathrm{NADP}^{+} / \mathrm{NADPH}$ that inhibits changes in pathways sensitive to oxidative during osmotic stresses caused by drought and salt stress. Accordingly, photochemical efficiency of PSII seems to be protected by proline while lipid peroxidation is inhibited during stresses caused by drought stress. These results suggest that when plants are affected by drought stress proline acts indirectly to preserve PSII in addition to direct scavenging ROS. By contrast, there is no idea about glycine betaine to scavenge ROS directly during abiotic stresses (Upadhyaya et al., 2013).

Under stress conditions, proline accumulation induction starts with modifications in synthesis and oxidation of the amino acid through increasing and reducing, respectively. During metabolism, most proline buildup in plants in reaction to stress is due to promoted biosynthesis from glutamate. In addition, proline may be biosynthesized 
from ornithine. Prolonged oxidation of proline is often associated with the onset of stress (Hare and Cress, 1997).

\section{Glycine betaine}

Glycine betaine (N, N, N-trimethylglycine) is one of the most important compatible solutes. It has wide preservative functions for plants that are exposure to drought, salinity and severe temperature stresses. The role of glycine betaine is the decreasing of the malondialdehyde contents to preserve the membrane systems (Roychoudhury and Banerjee, 2016). Cells are protected by glycine betaine from oxidative injury during environmental stresses. Glycine betaine accumulates primarily in the chloroplast and plays a role in maintaining photosystem II efficiency in stressful environments. Moreover, the treatment of exogenous glycine betaine treatment inhibits structural injuries from stress in organelles, such as chloroplasts and mitochondria that produce ROS (Upadhyaya et al., 2013).

Naturally, the content of this compound is low in plants, but transgenic plants can accumulate the high concentration of it. Transgenic Arabidopsis (by SDMT and GSMT) has had higher glycine betaine accumulation than in the transgenic lines overexpressing the choline oxidizing enzymes. These genes are from Aphanothece halophytica. Furthermore, spraying choline, which is the first compound in the biosynthesis pathway of glycine betaine, can promote the glycine betaine accumulation in plants (Roychoudhury and Banerjee, 2016).

Tomato plants (Lycopersicon esculentum Mill.) are among the plant that cannot naturally accumulate glycine betaine. Most genotypes cultivated with tropical genetic patterns suffer from chilling damage when are grown at temperatures below $10^{\circ} \mathrm{C}$. The temperatures below $13{ }^{\circ} \mathrm{C}$ may prevent fruit-set, while temperatures below $6^{\circ} \mathrm{C}$ may be fatal for plants. Although, glycine betaine cannot be naturally accumulated in plants, its exogenous usage enhances their tolerance to salinity, drought and chilling. However, the mechanisms by which glycine betaine promotes this stress tolerance are not completely understood (Park et al., 2006). Exogenous application of glycine betaine can improve unfavorable effects of heat on development of different crops. For instance, its spraying on Arabidopsis increased freezing resistance. Also, low temperatures tolerance has been promoted in two varieties of potato. In strawberry (Fragaria $x$ ananassa), the exogenous spraying of glycine betaine can enhance cold tolerance in non-acclimated and acclimated plants. Specifically, its application in unprotected plants of strawberry promoted their tolerance to low temperature by almost $200 \%$. Based on these effects, commercial use of glycine betaine can be suggested for farms of strawberries under cold stress (Ashraf et al., 2007).

The effects of the increased content of glycine betaine in the chloroplasts of a transgenic plant indicate that plants are more effectively preserved from environmental stresses when glycine betaine builds up in the chloroplasts using chloroplast targeted coda gene rather than within the cytosol. Furthermore, the amounts of chloroplast glycine betaine have relationship with the tolerance intensity. In genetically modified rice, photosynthesis protection is also better against salinity and low temperature stresses when the chloroplast-targeted codA gene is transformed into plants toward the non-targeted codA gene, which its products are primarily produced in the cytosol. It can be noted that through this genotype can biosynthesize by $500 \%$ more glycine betaine. The increased content of glycine betaine in the reproductive organs transgenic plants (with the accumulated qualities of glycine betaine) is also related to promoted tolerance with salinity and cold conditions, which also increases yield of plants. Therefore, the increased accumulation of glycine betaine in the meristems could improve tolerance of these organs and improves growth after cold stress conditions. When plants affected by chilling stress, treating plants with glycine betaine results in preserving low levels of $\mathrm{H}_{2} \mathrm{O}_{2}$ toward other plants, therefore, it seems that glycine betaine is not ineffective in scavenging ROS. That said, glycine betaine may indirectly increase oxidative stress tolerance, for example by stimulating catalase. $\mathrm{H}_{2} \mathrm{O}_{2}$ as a secondary messenger will signal the plant about stress. Although, its toxicity intensities lead to apoptosis, but even non-toxic amounts enhance expression of gene and promotes plant stress reactions. When $\mathrm{H}_{2} \mathrm{O}_{2}$ is its own low contents can stimulate preservation against oxidative stress, because it stimulates the expression of antioxidant enzymes, e.g. catalase, and then promotes chilling tolerance.

When glycine betaine is exogenously applied on plants, it takes effectively through the surface of tomato leaves and then moves it into various parts. The low level of glycine betaine $\left(>0.09 \mu \mathrm{mol} \mathrm{g}{ }^{-1} \mathrm{FW}\right)$ in tissues of the sprayed plants plays a role in protection against chilling temperatures. Most glycine betaine content is translocated within the cytosol. However, just a tiny quantity moves into the chloroplasts and possibly to other different compartments of cell. As a result of this action, photosynthesis is protected and chilling tolerance is enhanced in treated plants with glycine betaine. It is important to find large amounts of glycine betaine in the meristem such as the apices and buds in treated plants. High levels of glycine betaine in these tissues are believed to be crucial for plant preservation and promoting growth recovery after chilling stresses (Park et al., 2006). Therefore, the site of glycine betaine accumulation in cell compartments of plants has the important role on measure of its efficiency on the plant tolerance to stresses.

\section{Soluble carbohydrates}

Sugers, until now, are known as the best osmolytes to protect plants during stress conditions (Lippert and Galinski, 1992). During environmental stresses, soluble sugars have a role to organize ROS signaling and osmotic adjustments. Soluble sugars are essentials in metabolism processes. They protect different metabolism processes, including photosynthesis, mitochondrial respiration and oxidative pentose phosphate pathways from both ROS production and scavenging systems, including. For example, mannitol seems to be protecting chloroplastic apparatus from toxic damages caused by ${ }^{\bullet} \mathrm{OH}$ radicals during stress conditions. Also, trehalose as signaling molecule (disaccharide sugar) 
regulates the metabolism of carbon and $\mathrm{ABA}$ when plants are exposure to osmotic stress (Upadhyaya et al., 2013).

\section{Conclusions}

Cold stress is one of the important temperature stresses for farmers and plant growers worldwide. This paper highlights how to affect productivity and quality of plants by chilling stress. One of the defensive mechanisms in plants i.e. tolerance is described. Plants unlike avoidance mechanisms, which go to stop the activity such as dormancy, promote their metabolic activities. A complex of molecular, hormonal, enzymatic and non-enzymatic processes helps plant to have tolerance to these stresses. It can be stated that osmolytes especially proline, glycine betaine as nonenzymatic networks in different groups of plants, including ornamental and vegetative plants and crops that suffer cold have the important roles worldwide. These compounds can scavenge ROS, which is produced during oxidative stress as secondary stress, and also have role in osmotic adjustment.

\section{Author Contribution}

S.S.S.M. ${ }^{000-0001-5455-0970}$ : arranged the sub-titles and wrote the paper

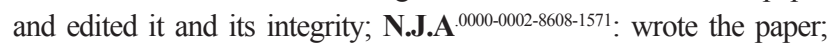
Y.N.S. ${ }^{0000-0002-4601-9757}$ : wrote about chilling stress effects on the plants.

\section{Acknowledgements}

The authors like to thank the Deputy of Research and Technology in Horticultural Sciences Research Institute (HSRI), Iran and Lebanese University, Lebanon for supporting to report this Review paper.

\section{References}

ABBAS, Z.K.; SAGGU, S., REHMAN, H.; AL THBIANI, A.; ANSARI, A.A. Ecological variations and role of heat shock protein in Artemisia judaica L. in response to temperature regimes of Tabuk, Saudi Arabia. Saudi Journal of Biological Sciences, v.24, n.6, p.1268-1273, 2017. DOI: 10.1016/j.sjbs.2016.01.001

ASHRAF, M.F.M.R.; FOOLAD, M. Roles of glycine betaine and proline in improving plant abiotic stress resistance. Environmental and Experimental Botany, v.59, n.2, p.206-216, 2007. DOI: 10.1016/j.envexpbot.2005.12.006

BURG, M.B.; FERRARIS, J.D. Intracellular organic osmolytes: function and regulation. Journal of Biological Chemistry, v.283, n.12, p.7309-7313, 2008. DOI: 10.1074/ jbc.R700042200

DELA, G.; OR, E.; OVADIA, R.; NISSIM-LEVI, A.; WEISS, D.; OREN-SHAMIR, M. Changes in anthocyanin concentration and composition in 'Jaguar' rose flowers due to transient high-temperature conditions. Plant Science, v.164, n.3, p.333-340, 2003. DOI: 10.1016/S01689452(02)00417-X
DENG, X.; WANG, J.; LI, Y.; WU, S.; YANG, S.; CHAO, J.; CHEN, Y.; ZHANG, S.; SHI, M.; TIAN, W. Comparative transcriptome analysis reveals phytohormone signalings, heat shock module and ROS scavenger mediate the cold-tolerance of rubber tree. Scientific Reports, v.8, n.1, p.4931, 2018. DOI: 10.1038/s41598-018-23094-y

FEDIUK, O.M.; BILYAVSKA, N.O.; ZOLOTAREVA, O.K. Effects of sucrose on structure and functioning of photosynthetic apparatus of Galanthus nivalis L. leaves exposed to chilling stress. Annals of the Romanian Society for Cell Biology, v.21, n.3, p.43-51, 2017.

FEI, J.; WANG, Y.S.; ZHOU, Q.; GU, J.D. Cloning and expression analysis of HSP70 gene from mangrove plant Kandelia obovata under cold stress. Ecotoxicology, v.24, n.7-8, p.1677-1685, 2015. DOI: 10.1007/s10646-0151484-y

GINDIN, E.; BOROCHOV, A. Ubiquitin conjugation to protein increases following chilling of Clerodendrum leaves. Plant Physiology, v.100, n.3, p.1392-1395, 1992. DOI: $10.1104 /$ pp.100.3.1392

HARE, P.D.; CRESS, W.A. Metabolic implications of stress-induced proline accumulation in plants. Plant Growth Regulation, v.21, n.2, p.79-102, 1997. DOI: 10.1023/A:1005703923347

HUANG, X.; SHI, H.; HU, Z.; LIU, A.; AMOMBO, E.; CHEN, L.; FU, J. ABA is involved in regulation of cold stress response in bermudagrass. Frontiers in Plant Science, v.8, p.1613, 2017. DOI: 10.3389/fpls.2017.01613

KAN, J.; XIE, W.; WAN, B.; HUO, T.B.; LIN, X.P.; LIU, J.; JIN, C.H. Heat induced tolerance to browning of fresh cut lily bulbs (Lilium lancifolium Thunb.) under cold storage. Journal of Food Biochemistry, v.43, n.5, p.e12816, 2019. DOI: $10.1111 /$ jfbc. 12816

LATEF, A.A.H.A.; CHAOXING, H. Arbuscular mycorrhizal influence on growth, photosynthetic pigments, osmotic adjustment and oxidative stress in tomato plants subjected to low temperature stress. Acta Physiologiae Plantarum, v.33, n.4, p.1217-1225, 2011. DOI: 10.1007/ s11738-010-0650-3

LIPPERT, K.; GALINSKI, E.A. Enzyme stabilization be ectoine-type compatible solutes: protection against heating, freezing and drying. Applied Microbiology and Biotechnology, v.37, n.1, p.61-65, 1992. DOI: 10.1007/ BF00174204

OSMOND, C.B.;AUSTIN, M.P.; BERRY, J.A.; BILLINGS, W.D.; BOYER, J.S.; DACEY, J.W.H.; NOBEL, P.S.; SMITH, S.D.; WINNER, W.E. Stress physiology and the distribution of plants. Bioscience, v.37, n.1, p.38-48, 1987. DOI: $10.2307 / 1310176$ 
PARK, E.J.; JEKNIC, Z.; CHEN, T.H. Exogenous application of glycinebetaine increases chilling tolerance in tomato plants. Plant and Cell Physiology, v.47, n.6, p.706-714, 2006. DOI: 10.1093/pcp/pcj041

RIVERO, R.M.; RUIZ, J.M.; GARCIA, P.C.; LOPEZLEFEBRE, L.R.; SÁNCHEZ, E.; ROMERO, L. Resistance to cold and heat stress: accumulation of phenolic compounds in tomato and watermelon plants. Plant Science, v.160, n.2, p.315-321, 2001. DOI: 10.1016/s0168-9452(00)00395-2

ROYCHOUDHURY, A.; BANERJEE, A. Endogenous glycine betaine accumulation mediates abiotic stress tolerance in plants. Tropical Plant Research, v.3, p.105$111,2016$.

UPADHYAYA, H.; SAHOO, L.; PANDA, S.K. Molecular physiology of osmotic stress in plants. In: Molecular Stress Physiology of Plants. Springer, India, 2013. p.179-192.

WANG, K.; BAI, Z.Y.; LIANG, Q.Y.; LIU, Q.L.; ZHANG, L.; PAN, Y.Z.; LIU, G.L.; JIANG, B.B.; ZHANG, F.; JIA, Y. Transcriptome analysis of chrysanthemum (Dendranthema grandiflorum) in response to low temperature stress. BMC Genomics, v.19, n.1, p.319, 2018. DOI: 10.1186/s12864018-4706-X

WANG, L.Z.; WANG, L.M.; XIANG, H.T.; LUO, Y.; LI, R.; LI, Z.J.; WANG, C.Y.; MENG, Y. Relationship of photosynthetic efficiency and seed-setting rate in two contrasting rice cultivars under chilling stress. Photosynthetica, v.54, n.4, p.581-588, 2016. DOI: 10.1007/s11099-016-0648-1
WANG, W.; VINOCUR, B.; ALTMAN, A. Plant responses to drought, salinity and extreme temperatures: towards genetic engineering for stress tolerance. Planta, v.218, n.1, p.1-14, 2003. DOI: 10.1007/s00425-003-1105-5

WANG, Y.; DAI, Y.; TAO, X.; WANG, J.Z.; CHENG, H.Y.; YANG, H.; MA, X.R. Heat shock factor genes of tall fescue and perennial ryegrass in response to temperature stress by RNA-Seq analysis. Frontiers in Plant Science, v.6, p.1226, 2016. DOI: 10.3389/fpls.2015.01226

YADAV, S.K. Cold stress tolerance mechanisms in plants. A review. Agronomy for Sustainable Development, v.30, p.515-527, 2010. DOI: 10.1051/agro/2009050

YONG, Y.B.; LI, W.Q.; WANG, J.M.; ZHANG, Y.; LU, Y.M. Identification of gene co-expression networks involved in cold resistance of Lilium lancifolium. Biologia Plantarum, v.62, n.2, p.287-298, 2018. DOI: 10.1007/ s10535-017-0767-y

YUAN, Y.; QIAN, H.; YU, Y.; LIAN, F.; TANG, D. Thermotolerance and antioxidant response induced by heat acclimation in Freesia seedlings. Acta Physiologiae Plantarum, v.33, n.3, p.1001-1009, 2011. DOI: 10.1007/ s11738-010-0633-4

ZHOU, A.; MA, H.; LIU, E.; JIANG, T.; FENG, S.; GONG, S.; WANG, J. Transcriptome sequencing of Dianthus spiculifolius and analysis of the genes involved in responses to combined cold and drought stress. International Journal of Molecular Sciences, v.18, n.4, p.849, 2017. DOI: $10.3390 /$ ijms 18040849 